\title{
The Effectiveness of Service Innovation Practices to Reduce Energy Consumption Based on Adaptive Theory
}

\author{
Yang Yang, Zhongqiu Li *(D) and Yingying Su \\ School of Management, Harbin Institute of Technology, Harbin 150001, China; yfield@hit.edu.cn (Y.Y.); \\ 17S010084@stu.hit.edu.cn (Y.S.) \\ * Correspondence: 15b910029@hit.edu.cn or lzqlzq2011@sina.com
}

Received: 25 July 2018; Accepted: 11 September 2018; Published: 17 September 2018

\begin{abstract}
Research on service innovation appears in several research disciplines, with important contributions in marketing, management, and operations research. The purpose of manufacturing enterprise service is to reduce energy consumption. We offer a new account based on an adaptive theory perspective. This paper investigates the relationship among three types of service innovation practices and service innovation performance in manufacturing enterprise. The study further examines environmental uncertainty as a moderator between service innovation practices and service innovation performance. Data collected from 59 manufacturing enterprises in China, and is analyzed and used to validate the article's theoretical and empirical contributions. The findings reveal that three types of service innovation practices have positive effects on service innovation performance. In addition, the results show that the effect of guide-based service innovation practices on service innovation performance is weakened in manufacturing enterprise when there are higher levels of environmental uncertainty. The effect of project-based service innovation practices on service innovation performance is weakened in manufacturing enterprise when there are higher levels of environmental uncertainty. Based on the results, this study provides implications for service innovation and support roles in fostering and sustaining innovation, which generate sustainable competitive advantage.
\end{abstract}

Keywords: service innovation practice; service innovation performance; manufacturing enterprise; environmental uncertainty

\section{Introduction}

In recent years, the high uncertainty of economic globalization and the prevailing market environment have exacerbated the challenges that confront manufacturing enterprises in a highly competitive business environment [1]. Sustainability is an important issue that manufacturing enterprise has been facing. An increasing number of studies began to focus on the role of innovation in the sustainable development of enterprises [2]. Moreover, innovation along with reasonable policies such as taxation or regulation can improve the efficiency of energy using, reducing energy consumption [3]. Intense market competition and price pressures drive manufacturing enterprises towards making service innovation as they attempt to obtain additional income and profits [4]. Service-oriented manufacturing enterprise has higher marginal revenue, such as cost competition. Good service can enhance customer loyalty and increase the likelihood of customers buying again. In addition, due to the intangibility of services, it becomes more difficult for competitors to copy the service, and the resulting competitive advantage of services is therefore more durable [5]. As service innovation is the guarantee of the sustainable development of an enterprise and has a certain boost to the rational use of energy, this paper focuses on service innovation. 
In the early industrial age, the main purpose of manufacturing enterprises is to pursue economic interests or satisfy customer needs. However, with the continuous consumption of natural resources, the existing economic development model gradually shows an unsustainable tendency. The expansion of the environmental resource crisis has triggered companies to think about how to use innovation to save energy and keep sustainability. First, service innovation often creates new operand resources to increase service productivity and enhance efficiency [6], which is an important strategy and a compulsory factor for sustainability [7]. McDonald's has introduced FastOrder to reduced labor costs and enhance efficiency. FastOrder is a system which allows customers to order meals without human interaction in some of its most frequently visited locations [8]. Second, service innovation can improve service quality and improve customers' willingness to consume again [9]. In order to enhance competitive advantage, manufacturing enterprises have gradually shifted the industrial chain to service-oriented manufacturing enterprise. Enterprises tend to use financial standards or other quantitative indicators to measure service innovation performance, such as sales figures and market share [10]. A number of world-class manufacturing enterprises, including IBM, General Motors and Philips, have used business transformation and service innovation to increase their competitiveness. It is in this context that service innovation has increasingly commanded the attention of academics, governments, policymakers, practitioners and service researchers.

Previous studies demonstrate that there are many similarities between product and service innovation [11,12]. The concepts and theories developed in product innovation can be easily applied in service innovation [13]. From service-dominant perspective, some researchers who view service innovation as outcome or change instead define value and all product innovations are service innovations [6]. As fast adaptation has become the key strategic capability of many organizations, adaptive theory, as an important perspective used in product innovation [14], can be used when researching service innovation [10-12]. Eisenhardt and Tabrizi summarize two basic paradigms of innovation process: compression strategy and experiential strategy [14]. The assumption of the compression strategy is that the innovation process is predictable and deterministic. It can be planned through a series of separate steps, then by shortening the time of each step, cross-executing successive steps and rewarding the developer to compress the process [14]. In the service management process, the best process is defined as a standard, which is conducive to maintaining controllable and continuous updates of product (service) development projects. The result is accelerated service development. The underlying assumption of the experiential strategy is that the innovation process is carried out under highly uncertain environment. Therefore, it is necessary to quickly establish mechanisms and flexible choices to cope with unclear and changing environments [14]. The adaptation process can be achieved both through large-scale structural changes and frequent small-scale changes in the company's formation process, such as service innovation. This paper builds upon this insight to analyze the relationship between service innovation practices and service innovation performance through the prism of adaptive theory. This is an important contribution, as numerous researchers emphasize that the service innovation domain remains underdeveloped and there is a clear and ongoing need for additional research in this area [15].

The primary objective of our research is to explain the association between service innovation practices and performance by drawing on adaptive theory. Guide-based service innovation practices refer to the benchmarking of first-class companies and customers. Specifically, it mainly refers to the service process based on the determined innovation direction, with the innovation direction including the reference and learning of the first-class companies, along with the internal and external demand orientation. Project-based service innovation practices refer to the formulation of plans, tests, and performance standards. Process-based service innovation practice, or changes in service delivery and/or development processes as defined by method, functionality, administration, or other features [16]. We examine the relationship between guide-based service innovation practices and performance, along with the relationship between project-based service innovation practices and performance based on compression view of adaptive theory, which presents innovation as a predictable 
or deterministic process. From this perspective, it is important to reduce the time committed to innovation and instead dedicate more time to planning [14].

We examine the relationship between process-based service innovation practices and service innovation performance by applying an experiential view of adaptive theory, which holds that innovation is a highly uncertain path that unfolds through opaque markets and technologies. Experiential strategy can better adapt to uncertain, changing and experiential environments [14]. In process innovation, frequent iteration can increase the probability of success and accelerate the innovation process. We select environmental uncertainty as a moderating variable and test its effect, with the intention of ascertaining if the positive impact of service innovation practices on service innovation performance will indeed be weaker for enterprises with high environmental uncertainty.

In attempting to obtain a deeper insight into the relationship between service innovation practices and performance, this study also seeks to identify a key boundary condition of our causal sequence. The compression view of adaptive theory indicates that innovation is composed by a series of predictable steps [14]. In situations of low uncertainty, the process of innovation is predictable and compression strategy presents itself as an appropriate recourse [14]. In contrast, situations of high uncertainty are better suited to an adaptable, flexible and organically integrated organization.

The structure of this article is as follows. The Literature Review discusses the differences between products and services, along with types of service innovation practices. The research method is then discussed before the article sets out research findings relating to the relationship between service innovation practices and service performance, along with the moderating role of environmental uncertainty (see Figure 1). The final section discusses the findings with reference to the existing literature, draws out implications for manufacturing enterprise and advances suggestions for future research.

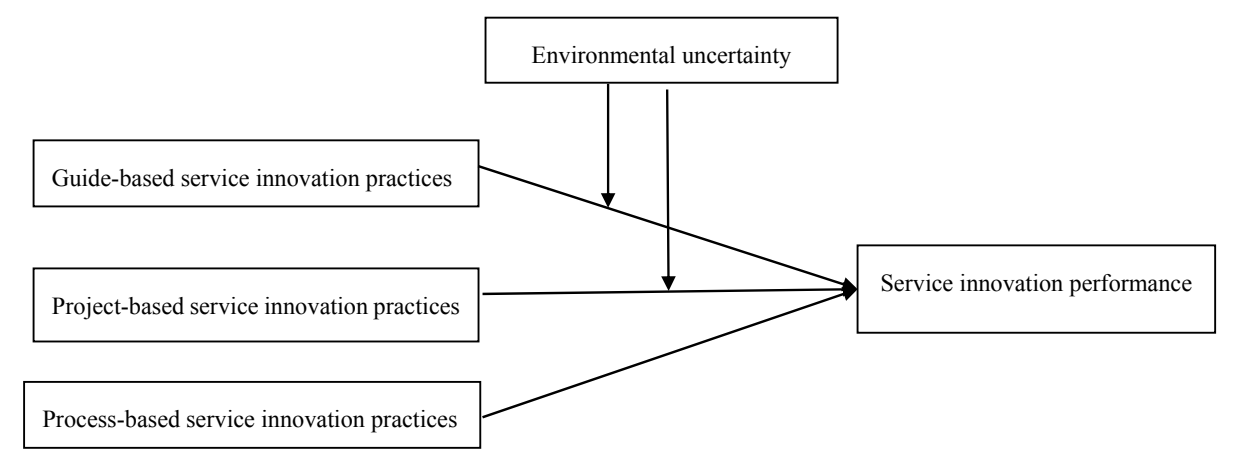

Figure 1. Research Model.

\section{Literature Review and Conceptual Framework}

The service innovation literature originated in the mid-1980s. Service innovation mainly refers to changes in the characteristics of the service itself [17]. Ostrom et al. suggest that service innovation creates value for customers, employees, business owners, alliance partners, and communities through new and/or improved service offerings, service processes, and service business models [18]. Consequently, adding service to innovation introduces new or alternate perspectives [19].

In the service innovation management literature, scholars have asserted that an organization should consider innovation management practices: innovation strategy, innovation process, cross-functional organization, tools/technology, and system integration for new service developments [20]. First, some researchers suggest that project learning $[16,21]$ and communication are critical to service development [22]. Still, others argue that customer experience management, use of customer information and brand differentiation are also important for service innovation practices [8,22-25]. Based on the above characteristics, we name this practice as guide-based service innovation. Second, some researchers hold that the use of phased assessment is conducive to the realization of innovation [26]. We name this practice as project-based service innovation. Third, a number of 
studies have focused broadly on investigating issues in new service development processes [16]. Managerial process innovation can be one of the important parts of guide [8,20,23,24,27-29]. Based on the above characteristics, we name this practice as process-based service innovation. In sum, to create new markets, firms must implement specific service innovation practices to provide managerial process innovation, develop scalar business models, manage customer experience and monitor employee performance [16]. The present study divides service innovation practices into three categories: guide-based service innovation practice, project-based service innovation practices and process-based service innovation practice.

\subsection{Guide-Based Service Innovation Practices and Service Innovation Performance}

Toivonen and Tuominen observe that service innovation is grounded within three assumptions; firstly, that innovation is carried into practice; secondly that it provides benefits to the developer; and finally, that it is reproducible [30]. Service innovation is a new service or a renewal of an existing service that is put into practice. It provides benefit to the organization, and this benefit usually derives from the added value that the renewal provides to customers [30]. In working to promote the success of service innovation, manufacturing enterprises need to cross existing knowledge boundaries and organizations, acquire and integrate new knowledge and increase the diversity of knowledge.

In this study, we examine the relationship between guide-based service innovation practices and service innovation performance by applying the compression view of adaptive theory. Excellent enterprises establish a basis for benchmarking and provide opportunities to learn lessons that potentially improve the service innovation performance of manufacturing enterprises. The rapid adaptability of fast pacing has become an important competitive asset of contemporary enterprises [31]. Adaptive theory asserts that innovation is a predictable or definite process that can be guided through a series of separate steps. By compressing the time of each step, we can achieve the same effect upon the process and the cross execution of successive steps while rewarding developers, thus contributing to the realization of the process of accelerating innovation. Compression is most effectively promoted by a shortening of the time committed to innovation and a more sustained commitment to planning [14]. In operating in accordance with the guidance of first-class companies, enterprises can establish a clear goal, develop a better understanding and plan more effectively. Good planning enables employees to better understand innovation and promotes good service innovation performance [32].

Secondly, by facilitating the identification of discrepancies between the internal and external needs of employees and customers, guide-based service helps enterprises to use resources more effectively when working towards the accomplishment of key goals. The guidance of internal and external needs enables us to attain a better understanding of the market because customer centeredness is the basic characteristic of the servitization of manufacturing; similarly, the changing role of the customer is an important difference that serves to distinguish service and traditional innovation [33,34]. Hence, service innovation becomes a new understanding of the formation of services that is grounded within the needs of consumers and changes in the environment. The specific mode of operation formed by this new understanding is a new idea or method that helps to solve problems that arise during the survival or development of the enterprise. The adoption of new management ideas, management methods and technical methods can bring about changes in the service processes of enterprises that create new value for customers [35].

Before making service innovation, enterprises often need to analyze existing services and competitive services-this then establishes the foundation for the consideration of the new service that can be provided to attract new customers and retain old customers. Just as service-dominant logic argues that all actors are resource integrators, and that this implies the significance of the roles and processes underlying value cocreation of customers [16]. It becomes easier to coordinate and organize the resources and capabilities of the enterprise, improve the service performance of the enterprise, resolve customer problems and understand customer needs [36]. Upon the basis of the preceding discussion, we propose the following hypotheses: 
Hypothesis 1. Guide-based service innovation practices positively relates to service innovation performance.

\subsection{Project-Based Service Innovation Practices and Service Innovation Performance}

Project-based service innovation practices mainly refers to the management and continuous improvement of the product development in the process of service innovation. It includes the commitment of time to the establishment of performance standards (for the development and improvement of related projects and services), the establishment of plans and the testing of new services.

We propose examining the relationship between project-based service innovation practices and service innovation performance by referring to the compression view of adaptive theory. Good planning can enable enterprises to avoid complicating factors and even wrong decisions in the process of service innovation. In instances where mistakes are unavoidable, delays will inevitably ensue, whether in the first or latter instance, with concomitant wastages of time and resources. Effective time planning will shorten project time by optimizing the process, resulting in errors being reduced and delays shortened [32].

Secondly, the compression view establishes that time committed to planning can assist employees by achieving access to resources, better interaction, cooperation among team members and reduced misunderstandings [14]; furthermore, it contends that each element contributes to the more rapid implementation of service innovation. Excellent planning is an important indicator of the quality of an innovative project [37]. The establishment of an effective and well-defined work rule is conducive to an independent work grounded within innovation and good practices [38].

Haier Group, is the world's largest home appliance brand. The development of Haier is consistent with this representation of the project-based service innovation practice. The provision of "high quality products" and "No defects in product quality" posited by Haier help to determine the product quality before instituting it as a performance improvement goal. And Haier sets a series product design, production and personnel assessment indicators around it, including horizontal performance targets, product customer satisfaction and vertical performance goals, which in turn establish indicators of competitive enterprise as a framework of reference. These goals, which are rooted in product platform and service platform, promote product and service innovation and further enhance the Haier brand's competitive advantage. Upon the basis of the preceding discussion, we propose the following hypothesis:

Hypothesis 2. Project-based service innovation practices positively relates to service innovation performance.

\subsection{Process-Based Service Innovation Practices and Service Innovation Performance}

Process innovation is one of important parts of innovation [39]. In contrast to physical goods, services are dynamic and unfold over time through a sequence or constellation of events and steps. The service process can be viewed as a chain or constellation of activities that allow the service to function effectively [40].

This study examines the relationship between process-based service innovation practices and performance by drawing upon the empirical view of adaptive theory. It is first important to note that the promotion of the continuous improvement of work processes and the establishment of milestones for the innovation process can contribute to the improvement of operation and management [41]. The empirical view of adaptive theory suggests that the frequent setting of milestones in the progress of innovation not only promotes communication between different departments but also arouses a sense of control and achievement in employees. The milestones provide the innovation process with an orderly point [42]. Information technology tools can also be used to enhance the role of network technology in internal communication, and can be applied to facilitate the interaction of innovative 
projects, and build a database that can draw lessons from practical experience, which help to realize the improvement of service performance through integration.

The empirical view of adaptive theory asserts that innovation follows an uncertain path through opaque and shifting markets and technologies. The key to rapid innovation is therefore to construct intuition and flexible options in order to quickly understand and adapt to uncertain environments [14]. Because strategic flexibility is the ability to handle change [43]. When the service process is repeatedly designed on the basis of previous experience, the designer needs to adjust in accordance with environmental requirements, with the intention of improving the cognitive processing of new information [31].

The innovation process can also be shortened by improving the confidence of the innovation team through circular design. The service innovation of an organic system and enhanced team engagement with the improvement of innovation performance can also be promoted through a range of innovations, which include the appropriate rewarding of the project team, the engagement of business experts, the formation of a cross-functional team and the highlighting of the role of the project of manager for the benefit of his/her staff. In the increasingly mature environment of e-commerce, IBM developed its service management including the enterprise's internal environment, the integration of management objectives and value, the management of the network environment and the management of the software and hardware infrastructure. Drawing upon the preceding discussion, we propose the following hypothesis:

Hypothesis 3. Process-based service innovation practices positively relates to service innovation performance.

\subsection{The Moderating Effect of Environmental Uncertainty}

Environmental uncertainty is a state in which managers are not able to predict the changes in the environment or future technology and market changes due to insufficient information and data about the external environment [44]. The business environment is more diversified and heterogeneous, and this makes the market dynamics and competition intensity of the enterprise environment more obvious [45]. The acquisition of accurate and timely customer knowledge will be more difficult in a highly volatile market environment. The greater the uncertainty risk faced by firms, the more difficult it will be to make correct judgment on the market, and this will ultimately be to the detriment of corporate performance [46]. In recent years, uncertainty in the process of service innovation has become established as a key research focus area. Uncertainty is closely related to service innovation-this is the question of how service innovation can be related to guide-based, process-based and project-based practices under uncertain environmental conditions. The research findings of Moenaert and Souder indicate that environmental uncertainties include uncertainties associated with competitors, resources and technology [47]. Changes in the external environment have variable regulatory effects on service innovation practice, and variation can similarly be identified in the service performance that is obtained.

Eisenhardt and Tabrizi propose to divide the basic innovation process into its compression and experience modes [14]. The underlying assumption of the compression strategy is that product development is a predictable or certain process, which can be planned as a series of discrete steps. This process can then be compressed by shortening the time of each step, with the consequence that successive execution steps overlap and developers are rewarded for attaining the compressed schedule. Accelerated product innovation development occurs as a result.

The preceding assumption in this instance is that innovation pursues an uncertain path through opaque and shifting markets and technologies. The key to fast product development is, therefore, the rapid construction of intuition and the establishment of flexible options: both are essential preconditions for learning about, and adapting to, uncertain environments [14].

We propose that high levels of environmental uncertainty will weaken the positive impact of role guide-based service innovation practices on service innovation performance. We also suggest 
that high levels of environmental uncertainty will weaken the positive impact of role project-based service innovation practices on service innovation performance. When the environment is uncertain, enterprises will increase research and development efforts for their own survival and development, while registering ongoing technological change. In order to develop effective competition strategies, enterprises will strengthen marketing investment. When environmental uncertainty is low, market demand and change trends remain relatively stable. In these circumstances, companies can choose to invest more capital in service innovation practices.

It is more effective to reward the project team for completing the project as planned and to strengthen the role of the project manager $[14,48]$. When an enterprise operates in an uncertain environment, it can adjust to this uncertainty by establishing a rapid response mechanism. The guidance of the first-class company can help the enterprise operating within the experiential mode to adopt more definite goals and directions, and this guarantees its service content and quality. But if the enterprise takes its guidance from internal and external customers, it cannot undertake effective and timely reflection that will help it to adjust to the high uncertainty of the environment or to sudden changes in market demand. The contributions will have no obvious effect in promoting the market performance of service innovation, and will not influence the improvement of the enterprise service performance $[49,50]$. In a stable environment, the adoption of guide and practice-based in manufacturing enterprises is more conducive to improvements in service performance. In an uncertain environment, where it is difficult to distinguish whether the compression or experiential mode should be pre-eminent in the process-based practice, environment uncertainty has no significant negative moderating effect on the relationship between process practices and service performance; enterprises should therefore adopt process practices and process class practice. We propose the following:

Hypothesis 4. Environmental uncertainty will moderate the relationship between guide-based service innovation practices and service innovation performance, such that this positive relationship will be weaker when there are higher levels of environmental uncertainty.

Hypothesis 5. Environmental uncertainty will moderate the relationship between project-based service innovation practices and service innovation performance, such that this positive relationship will be weaker when there are higher levels of environmental uncertainty.

In addition, the characteristics of services make it difficult to distinguish between the compression and experience modes of many practices in the process of service innovation. At this point, the service innovation practices are different and the process of product and service innovation needs to absorb the customer's opinion-the suggestion does not just rely on research and development (R\&D) staff [51]. When compared to product innovation, it becomes clear that the diversity of service innovation is an important part of its 'complicate' development.

In addition to the R\&D, other customers, employees, managers, suppliers and participants integrate into innovation activities and bring about interactions between multiple subjects [52]. In a context of environmental uncertainty, it is difficult for service innovation to distinguish between the compression and experiential modes in process-based practice. As has already noted, the experiential mode is better suited to uncertain environments. The overlap between the compression and experiential modes in service innovation practices results in environmental uncertainty exerting no significant negative moderating effect on process practice.

\section{Method}

\subsection{Sample and Data Collection}

In view of the data availability, industry characteristics and team research topic, this study selected manufacturing enterprise as the research object, and they are large-scale manufacturing enterprises that mainly produce and process various industrial products. Machinery and equipment manufacturing 
industry and metal assembly manufacturing industry are not included. The questionnaire used by this paper was designed by the school of management of Harbin Institute of Technology and conducted in cooperation with the China Machinery Industry Federation. First, preliminary survey was conducted. Then questionnaire was officially issued. The respondents were all professionals in the production and operation departments of manufacturing enterprises. During the data collection, we distributed questionnaires to 73 manufacturing enterprises. We received valid questionnaires from 57 manufacturing enterprises, for a response rate of $78.08 \%$.

\subsection{Variable Measurement}

To ensure accuracy of the questionnaire, the translation/back-translation procedure is followed to translate English-based measures into Chinese. Measures in this paper except control variable use the same response scale, ranged from 1 (strongly disagree) to 5 (strongly agree). We use market scale, speed of technological change market segmentation and market concentration to measure environmental uncertainty using a 5-point scale, which is shown in Appendix A. Considering the reliability and validity of the scale, maturity scales are adopted. Combined with the actual situation of China, the measurement items are revised and improved. Measurement items with opposite semantic meaning are deleted, and the measurement items with similar semantic expression are merged and deleted. A preliminary survey was conducted on some employees of the research enterprise to evaluate the appropriateness of the revised scale before the formal formation of the questionnaire. Then this study adjusted the scale according to the actual feedback of participants, forming the final scale. Finally, we establish the scales which include service innovation practices, environmental uncertainty and service innovation performance. Firm size, as control variable, is measured by the number of employees owned by the company.

Service innovation practices. According to the service innovation practices scale designed by Tidd and Hull, service innovation practices can be measured from three aspects: guide, project and process [53]. Among them, guide refers to the role of leading companies and customers as the benchmark. Project refers to the development of plans, tests and performance standards. Process refers to service innovation practices including continuous improvement, organization optimization, cross-functional teams, tools and technologies. As shown in Appendix A.

Environmental uncertainty. When analyzing environmental uncertainty, Justin Tan and Litscher divided it mainly from three aspects: dynamics, complexity and hostility [54]. Zahra designed a four-dimensional index scale including market share, consumer preference, competitors and industry legal norms [55]. Therefore, this study selects the changes in market scale, the speed of technological innovation, the state of market segmentation, and the degree of market concentration as four indicators to measure environmental uncertainty. The coefficient $\alpha$ is 0.97 .

Service innovation performance. This variable is based mainly on the scale developed by Storey and Kelly [56]. The index system of service innovation performance has been formed through modification and improvement.

Control variables. Firm size is taken as a control variable in this study. Humphrey, Schmitz and other scholars believe that large enterprises has more advantages of technical level and innovation ability compared with small enterprises, and they are innovative subjects with greater innovation power [57]. The firm size is related to innovation [58,59]. Therefore, firm size is selected as the control variable in this paper.

\subsection{Reliability and Validity Test}

After examination, the measurement scales of this study have good validity and reliability. Validity analysis includes content validity and structure validity. By referring to the research results of relevant literatures, it is ensured that the scale in this paper has a good content validity. For structure validity, this paper uses the factor analysis method, adopts the common factor cumulative interpretation rate, factor loading quantity index and others to test scale structure validity. Results are shown in the 
Table 1. Variable scale inspection results are reached $\mathrm{KMO}>0.6, p<0.001$, common factor cumulative interpretation rate $>50 \%$, factor loading $>0.5$, the scale has good structure validity. This paper uses Cronbachs $\alpha$ to test the reliability of the scale. The Cronbachs $\alpha$ of each variable scale is more than 0.7, indicating that the reliability of scale in this study was good.

\section{Data Analysis and Results}

In the analysis of variables of this study, the SPSS 22 statistical software was used. Then we used a hierarchical regression analysis to test the main effect, and then the moderating effect was tested.

\subsection{Correlation Analysis of Sample Variables}

Means, standard deviations, and correlation coefficients of variables are presented in Table 1. Consistent with our arguments guide-based service innovation practices is positively associated with service innovation performance $(r=0.453, p<0.01)$. Project-based service innovation practices is positively associated with service innovation performance $(\mathrm{r}=0.330, p<0.01)$. Process-based service innovation practices is positively associated with service innovation performance $(\mathrm{r}=0.305, p<0.01)$. These results provide preliminary evidence for our hypotheses.

Table 1. Descriptive Statistics, Correlations of Variables.

\begin{tabular}{|c|c|c|c|c|c|c|c|c|c|}
\hline & Variable & Mean & Std. & 1 & 2 & 3 & 4 & 5 & 6 \\
\hline 2 & Guide-based practice & 3.568 & 0.971 & $0.453 * *$ & 1 & & & & \\
\hline 4 & Process-based practice & 3.337 & 0.842 & $0.305^{* *}$ & 0.000 & 0.000 & 1 & & \\
\hline 5 & Environmental uncertainty & 3.281 & 0.686 & 0.213 & $0.405^{* *}$ & -0.141 & -0.042 & 1 & \\
\hline 6 & Firm size & 1245.700 & 2651.233 & 0.158 & $0.348 * *$ & 0.037 & 0.070 & $0.261 *$ & 1 \\
\hline
\end{tabular}

\subsection{Hypothesis Test}

As shown in Table 2, hierarchical regression analysis was adopted to test Hypotheses 1-5. Hypothesis 1, which predicted a positive relationship between guide-based service innovation practices and service innovation performance, was supported ( $\beta=0.447, p<0.01)$. Hypothesis 2 , which predicted a positive relationship between Project-based service innovation practices and service innovation performance, was also supported $(\beta=0.286, p<0.01)$. Hypothesis 3 , which predicted a positive relationship between process-based service innovation practices and service innovation performance, was supported $(\beta=0.347, p<0.01)$.

Then, the moderating effect of environmental uncertainty was tested. The results of the moderated hierarchical regression analyses for Hypothesis 4 were also show in Table 2. In the first step, the control variables are entered into the regression equation. In the second step, the independent variables are entered into the regression equation based on the first step. In the third step, the moderating variable and the interaction of the independent variable and moderating variable are entered together into the regression based on previous step. The interaction of guide-based service innovation practices and environmental uncertainty was negatively and significantly related to service innovation performance $(\beta=-0.311, p<0.01$, Model 3 in Table 2). The interaction of project-based service innovation practices and environmental uncertainty was negatively and significantly related to service innovation performance ( $\beta=-0.227, p<0.01$, Model 3 in Table 2).

In order to show the moderating effects more clearly, we draw the interaction effects, which is shown in Figure 2. The positive relationship between guide-based service innovation practices and service innovation performance is weaker with high environmental uncertainty rather than with low environmental uncertainty. The positive relationship between project-based service innovation practices and service innovation performance is weaker with high environmental uncertainty rather than with low environmental uncertainty. 
Table 2. Summary of Multiple Regression Analysis Results.

\begin{tabular}{|c|c|c|c|c|c|c|c|c|c|c|c|c|}
\hline \multirow{2}{*}{ Independent Variables } & \multicolumn{4}{|c|}{ Model 1} & \multicolumn{4}{|c|}{ Model 2} & \multicolumn{4}{|c|}{ Model 3} \\
\hline & B & Std. B & Sig. & VIF & B & Std. B & Sig. & VIF & B & Std. B & Sig. & VIF \\
\hline (constant) & 0.016 & & 0.902 & & 0.058 & & 0.652 & & 0.065 & & 0.620 & \\
\hline Firm size & 0.000 & 0.137 & 0.284 & 1.104 & 0.000 & 0.050 & 0.703 & 1.262 & 0.000 & 0.237 & 0.095 & 1.703 \\
\hline Guide-based & 0.447 & 0.472 & 0.001 & 1.127 & 0.368 & 0.388 & 0.005 & 1.275 & 0.375 & 0.396 & 0.003 & 1.400 \\
\hline Project-based & 0.286 & 0.327 & 0.010 & 1.026 & 0.309 & 0.354 & 0.005 & 1.041 & 0.383 & 0.439 & 0.001 & 1.204 \\
\hline Process-Based & 0.347 & 0.374 & 0.004 & 1.029 & 0.372 & 0.401 & 0.002 & 1.044 & 0.488 & 0.527 & 0.000 & 1.228 \\
\hline Environmental uncertainty & & & & & 0.239 & 0.261 & 0.069 & 1.438 & 0.257 & 0.280 & 0.039 & 1.531 \\
\hline Guide-based practices $\times$ Environment uncertainty & & & & & & & & & -0.311 & -0.331 & 0.014 & 1.445 \\
\hline Project-based practices $\times$ Environment uncertainty & & & & & & & & & -0.227 & -0.227 & 0.085 & 1.469 \\
\hline $\mathrm{R}^{2}$ & \multicolumn{4}{|c|}{0.440} & \multicolumn{4}{|c|}{0.487} & \multicolumn{4}{|c|}{0.596} \\
\hline$\Delta R^{2}$ & \multicolumn{4}{|c|}{0.440} & \multicolumn{4}{|c|}{0.047} & \multicolumn{4}{|c|}{0.109} \\
\hline Sig. of $\Delta R^{2}$ & \multicolumn{4}{|c|}{0.000} & \multicolumn{4}{|c|}{0.069} & \multicolumn{4}{|c|}{0.014} \\
\hline $\mathrm{F}$ & \multirow{2}{*}{\multicolumn{4}{|c|}{$\begin{array}{l}7.663 \\
0.000\end{array}$}} & \multirow{2}{*}{\multicolumn{4}{|c|}{$\begin{array}{l}7.226 \\
0.000\end{array}$}} & \multirow{2}{*}{\multicolumn{4}{|c|}{$\begin{array}{l}7.598 \\
0.000\end{array}$}} \\
\hline Sig. of Model & & & & & & & & & & & & \\
\hline
\end{tabular}
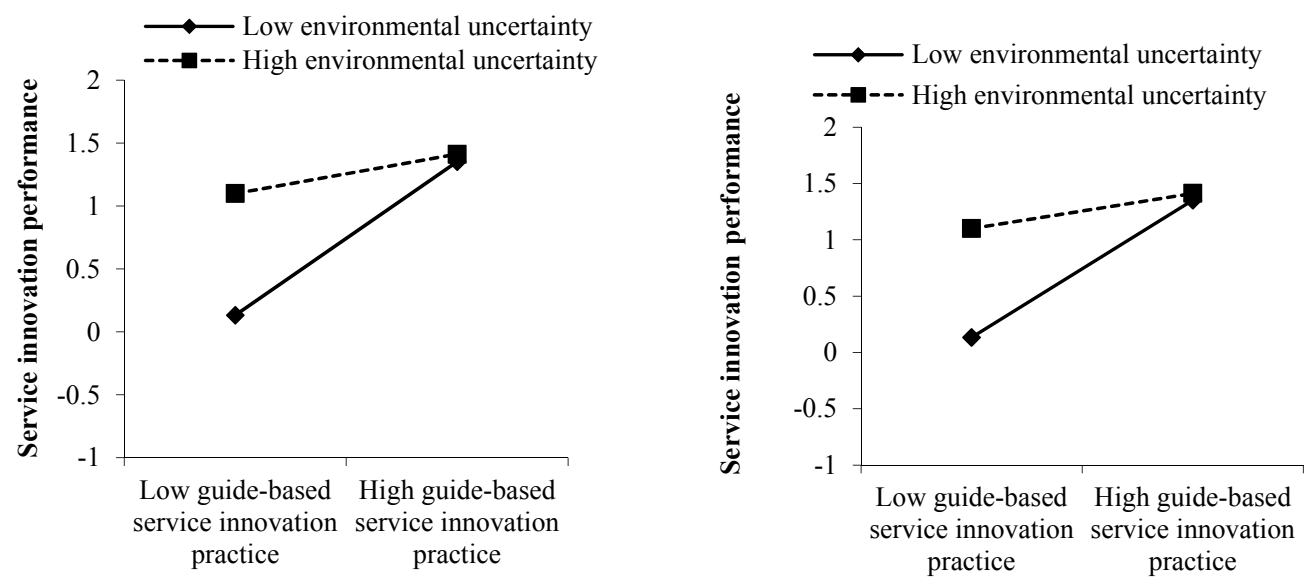

Figure 2. The Moderating Effect of Environmental Uncertainty. 


\section{Discussion and Conclusions}

The sustainability of manufacturing, including all manufacturing processes, such as customers, services, production process activities, should be done in a sustainable manner [60]. Service innovation is an important way to improve the competitiveness of enterprises [61], which will help sustainable development of the enterprise. So, we explored the positive effect of service innovation practices and performance in manufacturing enterprise and the moderating influence of environmental uncertainty in this relationship. The results support the use of adaptive theory to understand the association between service innovation practices and performance.

The empirical results demonstrate that guide-based service innovation practices positively relate to service innovation performance. In the practices of the service innovation, the use of the leading company as the benchmark can effectively reduce the cost of innovation and enhance the level of service innovation that derives from the strategy [41]. The guidance of internal and external customers can accelerate and deepen understanding of service innovation and thereby improve service innovation performance. Understanding user needs can be a competitive advantage for organization to applying practices of innovation [43]. In the process of expanding at the international level, Zte undertook strategic benchmarking with Vodafone while attaching great importance to 'market fundamentalism'. Internal and external market demand for technical personnel enabled it to withstand fierce competition from multinationals such as Alcatel, Cisco, Ericsson, Nokia and Siemens.

The empirical results demonstrate that there is a positive relationship between project-based service innovation practices and performance. The study of factors that influence product innovation attests that the early definition and evaluation of products, goal setting by developers and performance assessment have important positive effects on innovation performance [17]. The results of this study indicate that the formulation of planning and performance standards established clear goals for innovators. The incentive effect that formed as a consequence had a significant and positive impact on the improvement of service innovation.

The empirical results demonstrate that process-based service innovation practices and performance are positively related. This is consistent with the finding that the improvement of innovation performance requires the continuous improvement of process and organizational practices [62]. As the services being developed become fuzzier, development processes take on a more complex appearance. As a result, more effort and resources need to be committed to the management of the processes and the team that is engaged with the service innovation process [59].

Process management and continuous improvement increase procedures in the planning process and help managers to address difficulties and problems [38,63-65]. Service innovation performance also demonstrates a clear improvement. The interaction between customers and suppliers constitutes the core of service quality, which promotes sustainable development of enterprises [66].

Empirical results suggest that environmental uncertainty will weaken the relationship between guide-based service innovation practices and performance. Environmental uncertainty will, therefore, weaken the relationship between project-based service innovation practices and performance. This result is consistent with the recent finding suggesting that environmental uncertainty has a negative interaction effect on OCB performance because under high environmental uncertainty, the accuracy of strategy making and the speed of strategy implementation are important to improve performance [67]. When environmental uncertainty is high, enterprises place considerable emphasis upon technological changes, with the consequence that insufficient time and resources are committed to service innovation practices. In a highly uncertain environment, organizations cannot accurately understand or perceive the direction of environmental change, and the impact of environmental changes on the organization, along with the impact of specific actions, remains unclear. In an environment characterized by greater certainty, the adoption of guide-based practices and project-based practices in manufacturing enterprises appears more conducive to improvements in service performance. Thus, enterprise should pay attention to the external environment and a favorable 
business environment that can help promote and sustain innovation and industrial development should be create.

\section{Theoretical and Practical Implications}

Our findings have a number of implications for future research and theory. Our studies contribute to service innovation literature by offering an additional account to understand the relationship between service innovation practices and innovation performance. This extension is meaningful because it suggests that guide-based service innovation practices and project-based service innovation practices, as predictable or certain process, can be planned out as a series of discrete steps, help better understanding of service innovation and thus enhance innovation performance. Process-based service innovation practices, as a highly uncertain path through foggy and shifting markets and technologies, should rapidly building intuition and flexible options in order to learn quickly about and shift with uncertain environments.

Our findings on the moderating role of environmental uncertainty also strengthen the applicability of an accelerating adaptive theory perspective by explaining the link between service innovation practices and performance. We found that those with low environmental uncertainty are more likely to increase their working speed and therefore perform more service innovation performance after implementing service innovation practice. This is consistent with the recent finding that suggests environmental uncertainty has a negative interaction effect on performance [67].

Our findings have several implications for practitioners. Firstly, manufacturing enterprises can improve the performance of service innovation by implementing service innovation practices, specifically innovation-oriented benchmarking, innovation planning standardization and the perfection of innovation process. Service innovation practices can help manufacturing enterprises to cooperate with concurrent engineering, information and network technology and software (innovative and professional), enhance the enterprise market performance, expand the scope of the enterprise service and use online database tools to promote the improvement of enterprise service innovation performance.

Secondly, when operating within the current environment and adopting service innovation practice, manufacturing enterprises should acknowledge planning that establishes reasonable service performance standards and should also take the opportunity to learn from first-class enterprises. Manufacturing enterprises also should attach great importance to the guiding role of both internal and external customers and try to match service innovation practices with environmental conditions, in order to permit service innovation practices to perform its promoting role more effectively.

Thirdly, in operating in an uncertain environment, manufacturing enterprises should acknowledge the promotion effect of continuous process documentation and improve service organization and service scope when adopting service innovation practice. Manufacturing enterprises should provide full scope to customer participation in service innovation, promote the improvement of service innovation performance in an uncertain environment and regularly invite relevant business experts and constructively engage their opinions. Considering the fact that service innovation drives sustainable development, enterprise should pay more attention to service innovation performance.

\section{Limitations and Future Research}

The current research has some limitations; we hope that future research can solve these limitations. First, the sample size can be enlarged. The study operates within a strict industry definition, which limits its use for manufacturing enterprises of a certain size. This study was conducted at the same time as the International Manufacturing Strategy Survey (IMSS), and the production or operation supervisor was required as the subject of the survey. Therefore, the sample size of the study can be further expanded. Second, this study fails to dynamically observe changes in enterprise service innovation because of using cross sectional data. It is hoped that the longitudinal time series will be obtained by long-term tracking verification of model assumptions. 
Author Contributions: Y.Y. conceived the idea of this study, collected and analyzed relevant data; Z.L. prepared an initial draft of paper; Z.L. and Y.S. wrote this paper.

Funding: This paper is supported by grants from the National Natural Science Foundation of China (Project Numbers: 71372089).

Conflicts of Interest: The authors declare no conflict of interest.

\section{Appendix A}

Table A1. Variables to Measure Service Innovation Practices, Environmental Uncertainty and Service Innovation Performance.

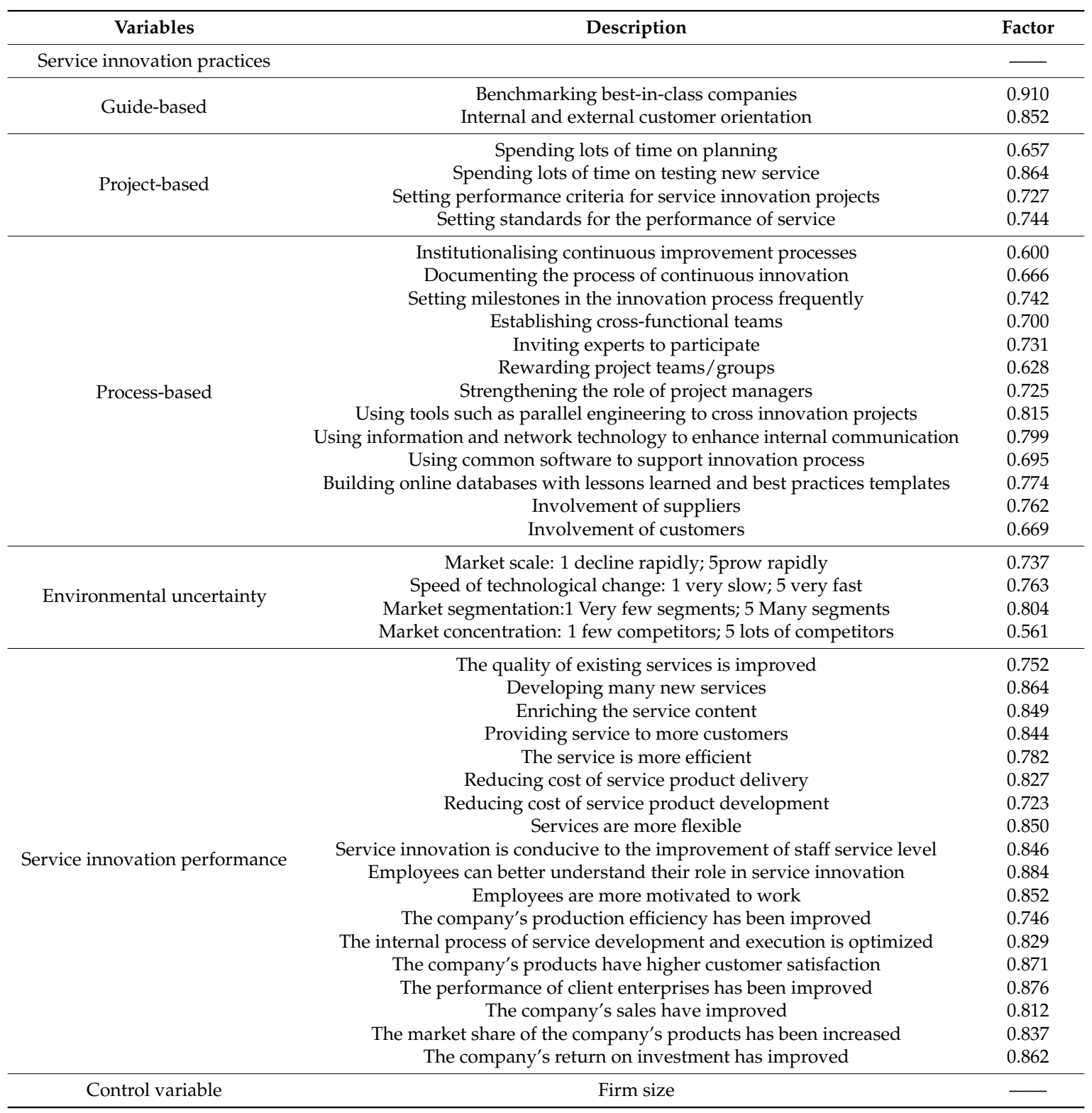

\section{References}

1. Chong, Y.L.; Zhou, L. Demand chain management: Relationships between external antecedents, web-based integratin and service innovation performance. Int. J. Prod. Econ. 2014, 154, 48-58. [CrossRef]

2. Ye, C.; Lim, U. Contextual factors affecting the innovation performance of manufacturing smes in Korea: A structural equation modeling approach. Sustainability 2017, 9, 1193. 
3. Herring, H.; Roy, R. Technological innovation, energy efficient design and the rebound effect. Technovation 2007, 27, 194-203. [CrossRef]

4. Gebauer, H.; Fleisch, E.; Friedli, T. Overcoming the service paradox in manufacturing companies. Eur. Manag. J. 2005, 23, 14-26. [CrossRef]

5. Gebauer, H.; Gustafsson, A.; Witell, L. Competitive advantage through service differentiation by manufacturing companies. J. Bus. Res. 2012, 64, 1270-1280. [CrossRef]

6. Lusch, R.F.; Nambisan, S. Service innovation: A service-dominant logic perspective. MIS Q. 2015, 39, $155-175$. [CrossRef]

7. Liedtke, C.; Buhl, J.; Ameli, N. Microfoundations for sustainable growth with eco-intelligent product service-arrangements. Sustainability 2013, 5, 1141-1160. [CrossRef]

8. Schaarschmidt, M. Frontline employees' participation in service innovation implementation: The role of perceived external reputation. Eur. Manag. J. 2016, 34, 540-549. [CrossRef]

9. Hossain, M.; Kim, M. Does Multidimensional Service Quality Generate Sustainable Use Intention for Facebook? Sustainability 2018, 10, 2283. [CrossRef]

10. Hsueh, J.T.; Lin, N.P.; Li, H.C. The effects of network embeddedness on service innovation performance. Serv. Ind. J. 2010, 30, 1723-1736. [CrossRef]

11. Griffin, A. PDMA research on new product development practices: Updating trends and benchmarking best practices. J. Prod. Innov. Manag. 1997, 14, 429-458. [CrossRef]

12. Sirilli, G.; Evangelista, R. Technological innovation in services and manufacturing: Results from Italian surveys. Res. Policy 1998, 27, 881-899. [CrossRef]

13. Nijssen, E.J.; Hillebrand, B.; Vermeulen, P.A.M.; Kemp, R.G.M. Exploring product and service innovation similarities and differences. Int. J. Res. Mark. 2006, 23, 241-251. [CrossRef]

14. Eisenhardt, K.M.; Tabrizi, B.N. Accelerating adaptive processes: Product innovation in the global computer industry. Adm. Sci. Q. 1995, 40, 84-110. [CrossRef]

15. Biemans, W.; Griffin, A. Innovation practices of b2b manufacturers and service providers: Are they really different? Ind. Mark. Manag. 2018, 4, 1-13. [CrossRef]

16. Chen, J.S.; Tsou, H.T. Information technology adoption for service innovation practices and competitive advantage: The case of financial firms. Inf. Res. Int. Electron. J. 2007, 12, 332-351.

17. De Jong, J.P.; Vermeulen, P.A. Organizing successful new service development: A literature review. Manag. Decis. 2003, 41, 844-858. [CrossRef]

18. Ostrom, A.L.; Bitner, M.J.; Brown, S.W.; Burkhard, K.A.; Goul, M.; Smith-Daniels, V.; Rabinovich, E. Moving forward and making a difference: Research priorities for the science of service. J. Serv. Res. 2010, 18, 127-159. [CrossRef]

19. Snyder, H.; Witell, L.; Gustafsson, A.; Fombelle, P.; Kristensson, P. Identifying categories of service innovation: A review and synthesis of the literature. J. Bus. Res. 2016, 69, 2401-2408. [CrossRef]

20. Tidd, J.; Bessant, J.; Pavitt, K. Managing Innovation: Integrating Technological, Market and Organizational Change, 2nd ed.; John Wiley \& Sons, Ltd.: Chichester, UK, 2001.

21. Blazevic, V.; Lievens, A.; Klein, E. Antecedents of project learning and time-to-market during new mobile service development. Int. J. Serv. Ind. Manag. 2003, 14, 120-147. [CrossRef]

22. Lievens, A.; Moenaert, R.K.; Jegers, R.S. Linking communication to innovation success in the financial services industry. Int. J. Serv. Ind. Manag. 1999, 10, 23-48. [CrossRef]

23. Atuahene-Gima, K. Differential potency of factors affecting innovation performance in manufacturing and services firms in Australia. J. Prod. Innov. Manag. 1996, 13, 35-52. [CrossRef]

24. Drejer, I. Identifying innovation in surveys of services: A Schumpeterian perspective. Res. Policy 2004, 33, 551-562. [CrossRef]

25. De Brentani, U. Success and failure in new industrial services. J. Prod. Innov. Manag. 1989, 6, $239-258$. [CrossRef]

26. Cooper, R.G.; Kleinschmidt, E.J. Benchmarking the firm's critical success factors in new product development. J. Prod. Innov. Manag. 1995, 12, 374-391. [CrossRef]

27. Avlonitis, G.J.; Papastathopoulou, P.G.; Gounaris, S.P. An empirically-based typology of product innovativeness for new financial services: Success and failure scenarios. J. Prod. Innov. Manag. 2001, 18, 324-342. [CrossRef] 
28. Chan, A.; Go, F.M.; Pine, R. Service innovation in Hong Kong: Attitudes and practice. Serv. Ind. J. 1998, 18, 112-124. [CrossRef]

29. Uchupalanan, K. Competition and information technology-based innovation in banking services. Int. J. Innov. Manag. 2000, 4, 455-489. [CrossRef]

30. Toivonen, M.; Tuominen, T. Emergence of innovations in services. Serv. Ind. J. 2009, 29, 887-902. [CrossRef]

31. Eisenhardt, K.M. Making fast strategic decisions in high-velocity environments. Acad. Manag. J. 1989, 32, 543-576.

32. Gupta, A.K.; Wilemon, D.L. Accelerating the development of technology-based new products. Calif. Manag. Rev. 1990, 32, 24-44. [CrossRef]

33. Baines, T.S.; Lightfoot, H.W.; Benedettini, O.; Kay, J.M. The servitization of manufacturing: A review of literature and reflection on future challenges. J. Manuf. Technol. Manag. 2001, 20, 547-567. [CrossRef]

34. Michel, S.; Brown, S.W.; Gallan, A.S. Service-logic innovations: How to innovate customers, not products. Calif. Manag. Rev. 2008, 50, 49-65. [CrossRef]

35. Sundbo, J. Management of innovation in services. Serv. Ind. J. 1997, 17, 432-455. [CrossRef]

36. Slater, S.F.; Narver, J.C. Customer-led and market-oriented: Let's not confuse the two. Strateg. Manag. J. 1998, 19, 1001-1006. [CrossRef]

37. Feldman, M.S.; March, J.G. Information in organizations as signal and symbol. Adm. Sci. Q. 1981, 26, 171-186. [CrossRef]

38. Damanpour, F. Organizational innovation: A meta-analysis of effects of determinants and moderators. Acad. Manag. J. 1991, 34, 555-590.

39. Uriona-Maldonado, M.; de Souza, L.L.C.; Varvakis, G. Focus on practice service process innovation in the Brazilian electric energy sector. Serv. Bus. 2010, 4, 77-88. [CrossRef]

40. Bitner, M.J.; Ostrom, A.L.; Morgan, F.N. Service blueprinting: A practical technique for service innovation. Calif. Manag. Rev. 2008, 50, 66-94. [CrossRef]

41. Winter, S.G.; Szulanski, G. Replication as strategy. Org. Sci. 2001, 12, 730-743. [CrossRef]

42. Weick, K.E. The collapse of sensemaking in organizations: The Mann Gulch disaster. Adm. Sci. Q. 1993, 38, 628-652. [CrossRef]

43. Brozovic, D. Strategic flexibility: A review of the literature. Int. J. Manag. Rev. 2018, 2, 3-31. [CrossRef]

44. Uzkurt, C.; Kumar, R.; Kimzan, H.S.; Sert, H. The impact of environmental uncertainty dimensions on organisational innovativeness: An empirical study on SMEs. Int. J. Innov. Manag. 2012, 16, 63-167. [CrossRef]

45. Zhou, K.Z.; Yim, C.K.; Tse, D.K. The effects of strategic orientations on technology-and market-based breakthrough innovations. J. Mark. 2005, 69, 42-60. [CrossRef]

46. Dai, W.; Liu, Y. Local vs. non-local institutional embeddedness, corporate entrepreneurship, and firm performance in a transitional economy. Asian J. Technol. Innov. 2014, 23, 255-270. [CrossRef]

47. Moenaert, R.K.; Souder, W.E. An information transfer model for integrating marketing and R \& D personnel in new product development projects. J. Prod. Innov. Manag. 2010, 7, 91-107.

48. Ulwick, A.W. Turn customer input into innovation. Harv. Bus. Rev. 2002, 80, 91-97. [PubMed]

49. MacCormack, A.; Verganti, R.; Iansiti, M. Developing products on "Internet time": The anatomy of a flexible development process. Manag. Sci. 2001, 47, 133-150. [CrossRef]

50. Easingwood, C.; Moxey, S.; Capleton, H. Bringing high technology to market: Successful strategies employed in the worldwide software industry. J. Prod. Innov. Manag. 2006, 23, 498-511. [CrossRef]

51. Dong, J.L.; Chen, J. Seamless open innovation: The product innovation model of Xiaomi in the internet ecosystem. Sci. Res. Manag. 2014, 12, 76-84. (In Chinese)

52. Homburg, C.; Grozdanovic, M.; Klarmann, M. Responsiveness to customers and competitors: The role of affective and cognitive organizational systems. J. Mark. 2007, 71, 18-38. [CrossRef]

53. Chesbrough, H.W. Open Innovation: The New Imperative for Creating and Profiting from Technology; Harvard Business Press: Brighton, MA, USA, 2006.

54. Justin Tan, J.; Litsschert, R.J. Environment-strategy relationship and its performance implications: An empirical study of the Chinese electronics industry. Strateg. Manag. J. 1994, 15, 1-20. [CrossRef]

55. Zahra, S.A. Goverance, ownership, and corporate entrepreneurship: The moderating impact of industry technological opportunities. Acad. Manag. J. 1996, 39, 1713-1735. [CrossRef] 
56. Storey, C.; Kelly, D. Measuring the performance of new service development activities. Serv. Ind. J. 2001, 21, 71-90. [CrossRef]

57. Galbraith, J.R. Designing Organizations: Strategy, Structure, and Process at the Business Unit and Enterprise Levels; John Wiley \& Sons: Hoboken, NJ, USA, 2014.

58. Shefer, D.; Frenkel, A. R\&d, firm size and innovation: An empirical analysis. Technovation 2003, 25, $25-32$.

59. Storey, V.M.; Raddats, C.; Burton, J.; Zolkiewski, J.; Baines, T. Capabilities for advanced services: A multi-actor perspective. Ind. Mark. Manag. 2016, 60, 54-68. [CrossRef]

60. Nasiri, M.; Rantala, T.; Saunila, M.; Ukko, J.; Rantanen, H. Transition towards sustainable solutions: Product, service, technology, and business model. Sustainability 2018, 10, 358. [CrossRef]

61. Horng, J.S.; Wang, C.J.; Liu, C.H.; Chou, S.F.; Tsai, C.Y. The role of sustainable service innovation in crafting the vision of the hospitality industry. Sustainability 2016, 8, 223. [CrossRef]

62. Kirner, E.; Kinkel, S.; Jaeger, A. Innovation paths and the innovation performance of low-technology firms-An empirical analysis of German industry. Res. Policy 2009, 38, 447-458. [CrossRef]

63. Pierce, J.L.; Delbecq, A.L. Organization structure, individual attitudes and innovation. Acad. Manag. Rev. 1977, 2, 27-37. [CrossRef]

64. Dewar, R.; Werbel, J. Universalistic and contingency predictions of employee satisfaction and conflict. Adm. Sci. Q. 1979, 24, 426-448. [CrossRef]

65. Nahm, A.Y.; Vonderembse, M.A.; Koufteros, X.A. The impact of organizational structure on time-based manufacturing and plant performance. J. Oper. Manag. 2004, 35, 579-607. [CrossRef]

66. Na, Y.; Kang, S. Sustainable diffusion of fashion information on mobile friends-based social network service. Sustainability 2018, 10, 1474. [CrossRef]

67. Lin, X.U.; Liu, C.L.; Yang, X.Y.; Management, S.O.; University, N. Pay dispersion within top management team and firm performance-Moderating effect of environmental uncertainty. Econ. Manag. J. 2015, 4, 61-70. (In Chinese)

(C) 2018 by the authors. Licensee MDPI, Basel, Switzerland. This article is an open access article distributed under the terms and conditions of the Creative Commons Attribution (CC BY) license (http://creativecommons.org/licenses/by/4.0/). 